\title{
PENANAMAN SPIRITUAL REMAJA KARANG TARUNA MELALUI PENGKAJIAN KITAB HIKAM DI DESA KARANGREJO KECAMATAN GEMPOL PASURUAN
}

\author{
Zainal Fanani, Ahmad Ma'ruf \\ ahmadmaruf@yudharta.ac.id \\ Universitas Yudhrata Pasuruan
}

\begin{abstract}
Karang Taruna's spiritual planting approach through the study of the Hikam book in Karangrejo Village, Gempol Subdistrict was carried out and guided directly by the leaders and caretakers of the Taklim Assembly in ways of humanism preaching such as Walisango using several approaches including; experience, which means providing a spiritual experience with the concept of the experience of the salaf cleric, habituation which means caretakers of the taklim assemblies provide istiqomah learning by slowly leading the youth Karang Taruna, emotional which means changing negative emotional overflowing in youth Karang Taruna carried out in the past then those who have been trapped in a negative environment become close to their god, rational, which means giving knowledge to the youth of Karang Taruna proportionally that is acceptable with reason so that it is easily practiced, functional which means that al-Hikam's learning can produce results and later teaching can be implemented in the youth of Karang Taruna and the last form of exemplary which means giving a factual example to the youth of Karang Taruna with the object of good behavior giving a model in the form of their capacity.
\end{abstract}

Keywords: Spiritual, teenagers, Kitab Kuning

\section{PENDAHULUAN}

Penanaman spiritual merupakan proses menumbuhkan jiwa rohani yang ada dalam diri manusia, karena jiwa tersebut merupakan aspek terpenting dalam diri manusia yang keguanaanya mengantarkan dekat dengan tuhan. Tentu hal itu harus melalui pendekatan penanaman spiritual, di dalam kitab al-Hikam disebutkan ada beberapa proses pendekatan yang harus dilalui ketika menjalankan ibadah spiritual. ${ }^{1}$ Diantaranya, membersihkan dan

\footnotetext{
${ }^{1}$ Muhammad Arifuddin, (2018), Corak Tasawuf Kitab Hikam Karya Ibn 'Athaillah AsSakandari Dan Implikasinya Dalam Pembentukan Akhlak Di Pondok Pesantren Mambaus Sholihin Suci Manyar Gresik, Masters Thesis, UIN Sunan Ampel Surabaya. 2018. Hal. 71
} 
menghilangkan segala penyakit-penyakit atau dosa-dosa yang berkenaan dengan hati, seperti hawa nafsu, sifat tama'dan semua sifat yang membuat seorang hamba menjauh dari Allah SWT. Setelah dibersihkan, maka akan diisi dengan perbuatan-perbuatan yang terpuji yang sekiranya bisa menghindarkan dari perbuatan tercela. Proses puncaknya ialah ketika kedua tahap terlaksana maka seorang hamba dan tuhan tidak ada hijab seakan-akan dekat dengan tuhannya. ${ }^{2}$

Al-Hikam merupakan kitab yang bisa dijadikan sebagai acuan pada penanaman spiritual. Di dalam al-Hikam mengandung unsur-unsur dan cara yang diperuntukkan bagi seseorang yang mau melaksanakan kedekatan dengan sang khaliq.

Subtansi penanaman spiritual yang ada di dalam kitab al-Hikam mengacu pada proses belajar tasawuf dengan tulisan kitab yang bervariasi nada atau syair indah (aphorisms) ${ }^{3}$ yang ditulis oleh Ibn 'Athaillah. Tentunya dalam menggapai puncak spiritual tidak lepas dengan penanaman atau bimbingan spiritual. Karena tidaklah mungkin seseorang dalam mencapai kesuksesan spiritual tanpa adanya proses bimbingan dan penanaman yang ada dalam kitab al-Hikam.

Nilai-nilai spiritual yang ada dalam kitab Syech Ibn 'Atha'illah diimplementasikan pada remaja, maka arahnya ialah bagaimana pembelajarannya tersebut memberi stimulus pada diri seorang remaja, mengenai nilai-nilai spiritual tersebut. Bahwasanya nilai spiritual akan berbuah hasil dengan pembentukan karakter dan moral sebagai perwujudan dari nilai-nilai luhur. ${ }^{4}$

Pembelajaran nilai-nilai spiritual yang terkandung dalam kitab Hikam karya Ibn 'Atha'illah, disubtansikan menjadi tiga unsur antara lain: Islam, Iman dan Ihsan. Kitab hikam menjadi kitab yang fenomenal dikalangan masyarakat sekarang, diberbagai instansi pendidikan pesantren maupun non pesantren. Mengenai subtansinya kitab hikam memang banyak berbicara tentang Akhlak kepada Allah (tasawuf) maupun sesama manusia, tetapi esensinya kitab tersebut tidak lepas dari nilai-nilai spiritual yang dikemas

\footnotetext{
${ }^{2}$ Ibid, muhammad arifuddin, hal 80

${ }^{3}$ Jauhari, M. A. (2017). Perilaku Sosial Santri Pondok Pesantren Al-Ishlah Bandar Kidul Mojoroto Kota Kediri Setelah Mengikuti Pengajian Kitab Al-Hikam. Spiritual, vol. 1 no.1, Hal. 2

${ }^{4}$ N. Ainiyah, (2013). Pembentukan Karakter Melalui Pendidikan Agama Islam. Al-Ulum, 13 (1), Hal. 28
} 
menjadi nilai-nilai Akhlak kepada Allah SWT. Berisi nilai-nilai spiritual, nasihat-nasihat tentang akhlaq atau etika kepada tuhan serta narasi tentang hakikat manusia Dalam hal ini nilai spiritual memang banyak asumsinya, tetapi asumsi dalam konteks ini mengarah kepada keadaan rohani dalam kaitannya kedudukan seorang hamba dengan sang khaliq. ${ }^{5}$

Islam, Iman, dan Ihsan. Ketiga item merupakan pondasi terpenting dalam penanaman spiritual. karena harus dipahami oleh umat Islam secara keseluruhan, baik menurut epistemologi maupun terminologi. Tentu dengan mengkaji kitab-kitab yang berhubungan dengan tiga item tersebut. Seorang muslim dikatakan sempurna mengenal ajaran agamanya jika paham dalam tiga hal tersebut. ${ }^{6}$ Lantas bagaimana cara mengenal ketiganya, diantara Islam, Iman, dan Ihsan. Seseorang dapat belajar ketiganya melalui beberapa pengkajian kitab-kitab klasik karangan ulama' kuno. Antaranya jika kita ingin tahu ajaran Islam maka perlu memahami ajaran Syariat melalui pengkajian kitab fiqih maupun usul fiqih. Adapun mengenai Iman seseorang dapat mengkaji seperti halnya ilmu tauhid yang telah banyak dikarang oleh ulama' kuno atau salaf. Dan sampai sekarang kitab-kitab tersebut masih banyak yang mengkajinya. Baik kitab-kitab klasik maupun kontemporer. Yang ketiga, mengenai pengkajian Ihsan, secara singkat Ihsan merupakan perbuatan yang mengarah pada sifat-sifat keruhanian antara hamba dengan Tuhannya.

Nilai-nilai keruhanian/spirtitual akan peneliti uraikan melalui pengkajian kitab hikam yang sudah mashur dikalangan pesantren, dikarang oleh asy-Syekh al- Imamul Muhaqqiq al-Ariful Mukasyafah al-Walir Abul Fadil Tajuddin Abu al-Fadl Ahmad bin Muhammad bin Abdul Karim bin Abdurrahman bin Abdullah bin Ahmad bin isa bin al-Husain bin Athaillah alJudami al-Maliki al-Iskandari atau as-Sakandari al-Qarafi as-Sufi asySyadili. $^{7}$

\footnotetext{
${ }^{5}$ Zaitur Rahem, Ajaran Pendidikan Anti Korupsi Ibnu Athaillah(Menggali Nilai Pendidikan Moral-Spiritual Dsari Sebagian Untaian Hikmah Kitab Al-Hikam), Jurnal Pendidikan Dan Manajemen Islam, Volume 6, Nomor 2, Desember 2017 Hal. 589.

${ }^{6}$ Muhammad Sholikhin, Filsafat Dan Metafisika Dalam Islam (Sebuah Penjelajahan Nalar, Pengalaman Mistik, Dan Perjalanan Aliran Manunggaling Kawula Gusti), Narasi, Yogyakarta: 2008, Hal 222

${ }^{7}$ Achmad Beadie Busyroel Basyar, Pemikiran Ibnu Athaillah As-Syakandari Tentang Pendidikan Sufistik Dan Relevansinya Dengan Pendidikan Karakter Di Indonesia (Telaah Kitab Al-Hikam Al-Atiyah), Tesis, Jurnal Uin Maliki, Thn 2016, Hal. 64
} 


\section{4 ][ Penanaman Spiritual Remaja Karang Taruna Melalui Pengkajian Kitab Hikam}

Ulama' sekarang banyak yang mengajarkan kajian kitab Hikam, baik berbasis Pesantren maupun masyarakat umum. Kitab Hikam memang dominan ta'limnya di pesantren dan biasanya yang diajarkan dalam bentuk sorokan ala pesantren, maka tidak heran jika santri sudah terbiasa dengan pengkajian kitab Hikam. Namun hal demikian berbeda, jika kitab Hikam diajarkan pada desa-desa terpencil yang juru bicaranya bukan kyai $^{8}$ Mungkin yang peneliti maksud disini berbeda dari konteks pengkajiannya. Jika di lingkungan pesantren lebih dominan pada sorokan, namun pengkajian di desa-desa hanya berfokus pada materi-materi pengajaran melalui lisan sehingga peran masyarakat hanya mendengarkan dan menghayati apa yang disampaikan oleh guru.

Keharusan remaja yang belajar penyucian jiwa akan kaya nilai-nilai spiritual, berbuah menjadi akhlaq-akhlaq karimah yang bisa diimplikasikan pada hidup sehari-hari. Belajar akhlaq yang diimplikasikan terhadap sesama manusia maupun kepada Tuhan melalui doktrin kitab Hikam memang sangat tepat. Pada era yang global ini mungkin banyak anggapan atau asumsi yang mengklaim bahwa hampir punah remaja-remaja religius dimata masyarakat. Tentunya opini tersebut masih bersifat anggapan belaka belum pasti benarnya. Mungkin benar disisi lain dan bisa salah disisi yang lain. Remaja itu cenderung ekstrem pergaulannya. Seperti halnya di sosial media banyak kasus-kasus yang korbannya remaja. ${ }^{9}$

Salah satu krisis yang sangat menonjol pada dekade ini terutama pada kalangan remaja ialah pelajar yang sering praktik pelanggaran moral dengan ditandai sifat-sifat ketidakjujuran, tidak bertanggungjawab, rendahnya disiplin, rendahnya komitmen kepada nilai-nilai kebaikan. Sifat- sifat itulah yang perlu digaris bawahi, perlu bagi kita waspadai dan terlebih dihindari. Untuk menumbuhkan Benteng yang kuat perlu adanya bimbingan secara spiritual. ${ }^{10}$

Remaja saat ini tidak cukup cerdas dalam pengetahuan saja, tetapi didorong cerdas secara spiritual. Penanaman remaja diisi dengan pola belajar akhlaq dan tasawuf merupakan hal yang indah yang bisa di terapkan didunia

\footnotetext{
${ }^{8}$ Perbedaan Lingkungan Pesantren Dengan Lingkungan Pedesaan, Jika Pesantren Pengajaran Hikam Dilakukan Tidak Hanya Ngaji Kitabnya, Akan Tetapi yang paling penting Dalam Kehidupan Sehari-Harinya Cara Mengimplementasikan Dengan Melalui Lingkungan Teman pesantren Maupun Dengan Pengasuh.

${ }^{9}$ Ali Rahman, Pengaruh Negatif Era Teknologi Informasi Dan Komunikasi Pada Remaja (Persepektif Pendidikan Islam), Jurnal Studi Pendidikan, Vol 14 No. 1, Thn 2016, Hal 24

${ }^{10}$ Ibid, Ali Rahman, hal. 25
} 
nyata. Salah satunya kitab karangan ulama besar yaitu Ibnu 'Athaillah ${ }^{11}$ yang merupakan kitab yang berbau Spiritual-Agama yang mungkin sangat cocok dipelajari oleh remaja saat ini.

Kitab hikam berisi bagaimana cara mengatur hati dari lalainya ingat Allah SWT. Juga memberikan motivasi-motivasi bagi seorang hamba dalam menjalankan ubudiyah yang berkenaan dengan ibadah seorang hamba dengan Tuhannya. Dorongan secara spiritual memang sangat diperlukan dalam setiap hamba. Buktinya semakin belajar kitab hikam secara mendalam, maka semakin tahu hal-hal yang berbau tasawuf yang ujungnya mengarah pada nilai-nilai spiritual.

Penanaman nilai spiritual melalui Kitab hikam, maka arahnya ialah bagaimana pengkajian kitab hikam tersebut memberi stimulus pada diri seorang remaja, mengenai nilai-nilai spiritual tersebut. Bahwasanya nilai spiritual biasanya akan berbuah hasil dengan nilai-nilai akhlaq mulia. Dengan pengkajian kitab hikam, remaja diharapkan mampu memiliki tambahan stimulus nilai-nilai spiritual yang terkandung dalam kitab hikam. Baik cakap dari sisi teori maupun cakap dari segi implikasi dalam dunia yang nyata.

Dorongan spiritual terjadi tidak hanya mengacu pada pengkajian kitab al-Hikam saja tetapi bisa mempraktekan pengalaman-pengalaman keseharian yang berupa ibadah. Seperti mengamalkan ibadah lima waktu shalat sunnah dll., ini juga bagian dari aktivitas keruhanian. Niali-nilai agama dalam keseharian yang berkembang akan menghasilkan moral yang baik. ${ }^{12}$ Karena moral perlu menjadi pioritas dalam kehidupan sehari-hari. Adanya panutan nilai, moral dan norma dalam diri manusia akan sangat menentukan totalitas dari diri manusia serta lingkungan sosial serta kehidupan individu. Oleh karena itu, penanaman nilai spiritual melalui kajian hikam akan mengharapkan bagaimana bisa membentuk kapasitas manusia menjadi insan kamil.

Dalam hal ini peneliti implementasikan bagaimana Penanaman nilainilai spiritual pada kalangan pemuda.. Pemikiran serta ide-ide pemudalah

\footnotetext{
${ }^{11}$ Beliau mempunyai nama lengkap Tajul-Din Abu'l Fadl Ahmad ibn Muhammad ibn 'Abd al-Karim ibn Atha 'illah al-Iskandari al-Syadzili adalah tokoh Tarekat Syadziliyah. beliau lahir di Iskandariah (Mesir) pada 648 H/1250 M, dan meninggal di Kairo pada 1309 M. Beliau mempunyai karangan kitab diantaranya Al-Tanwir fi Isqath Al-Tadbir, Unwan AtTaufiq fi'dab Al-Thariq, Miftah Al-Falah dan Al-Qaul Al-Mujarrad fil Al-Ism Al-Mufrad. ${ }^{12}$ Endah Endrayani, (2012). Pembinaan Moral Spiritual Siswa Melalui Pembiasaan Shalat Jamaah (Studi Analisis Siswa MTs Miftahussa'adah Mijen Semarang) (Doctoral dissertation, IAIN Walisongo). Hal 21 hal 13.
} 


\section{6 ][ Penanaman Spiritual Remaja Karang Taruna Melalui Pengkajian Kitab Hikam}

yang bisa menjadikan desa maju serta berkembang. Namun disisi lain, remaja atau pemuda tidak sempurna pengetahuannya jika tidak dimasuki dengan nilai-nilai spiritual, maka akibatnya banyak remaja desa atau dikampungkampung yang menyepelekan masalah keruhanian.

Kehidupan spritual perlu diperhatikan secara mendalam terutama pada diri seorang remaja, dan harus ditanamkan sifat-sifat tasawuf dalam diri mereka. Karena remaja menjadi generasi yang paham dalam mengintegrasikan nilai-nilai akhlak, iman, dan pengetahuan. ${ }^{13}$ hal yang dominan pada usia remaja ialah faktor- eksternal yang sangat berpengaruh seperti halnya era globalisassi yang sangat berpengaruh, perlu adanya penyaring atau pembimbing spiritual yang mampu mencegah atau membendung dari sisi negatif globalisasi. Maka, penanaman unsur keruhanian pada remaja harus ditanamkan waulapun kenyataannya masih belajar dalam tahap implementasikan. Sifat ruhaniyah yang ditanamkan pada remaja memang harus bertahap sesuai dengan kemampuan masing-masing.

\section{PENDEKATAN PENANAMAN SPIRITUAL}

Penanaman spiritual yang dilakukan remaja karang taruna Di Desa Karangrejo Kecamatan Gempol setiap minggunya banyak melakukan rutinitas keagamaan di dalam Desa. Terutama pada hari rabu dan kamis mereka mempunyai acara ritualitas keagamaan yang di pimpin langsung oleh ustadz masruh yang mana beliau merupakan pimpinan sekaligus pengasuh dari majelis taklim di desa karangrejo. Beliau mengungkapkan beberapa kalimat dalam wawancara sebagai berikut:

"kegiatan disini hanya hari rabu dan kamis, namun saya sampaikan kepada jamaah disini harus diamalkan sehari-hari dirumah meskipun di tempat sini hanya satu minggu dua kali (rabu dan kamis) tapi berharap amaliah yang sudah di wulangno bisa dijalankan pada diri jamaah"14

Beliau mengungkapkan bahwa kegiatan pendidikan keagamaan yang ada di desa karangrejo merupakan aset sangat penting bagi aktivitas remajaremaja di desa karangrejo. Tidak hanya itu mereka harus siap mengamalkan di rumah masing-masing artinya harus di istiqomahkan meskipun satu minggu hanya rabu dan kamis.

13 Miftahul Jannah, (2017). Remaja dan Tugas-tugas Perkembangannya dalam Islam. Psikoislamedia: Jurnal Psikologi, vol.1 no.1Hal. 247

${ }^{14}$ Masruh, Pimpinan Majelis Taklim, Wawancara, Karangrejo, 14 Mei 2019. 
Penanaman spiritual melalui kitab al-Hikam terhadap pemuda karang taruna desa karangrejo tentu tidak lepas dengan alur atau cara penanaman spiritual yang mana diberlakukan beberapa pendekatan dengan tujuan agar yang diajarkan kepada para remaja karang taruna bisa merasuk ajarannya. diantaranya; pengalaman, pembiasaan, emosional, rasional, fungsional dan keteladanan.

1. Pengalaman

Pengalaman yang diberikan kepada remaja karang taruna tidak lain ialah pengalaman tasawuf melalui kitab al-Hikam, di dalam pengkajian yang dilakukan oleh ustadz masruh mengandung banyak nilai-nilai keagamaan yang sangat cocok untuk kehidupan para remaja karang taruna. $^{15}$ Setiap kali pengkajian beliau selalu mengungkapkan pengalaman-pengalaman para sufi yang ada zaman dahulu. Seperti ulama' kuno yaitu abi yazid al-bustomi, abil hasan asy-syadili, ibnu athaillah asySyadily.

Dalam kitab al-hikam banyak sekali ungkapan-ungkapan tasawuf yang ditulis oleh 'ibn athaillah yang telah diberikan kepada remaja-remaja sesuai dengan kadar mereka yang dialami. Ustadz masruh ketika dalam setiap pertemuan tidak langsung banyak mengungkapkan banyak sekali qishoh atau cerita-cerita yang banyak, tetapi secara bertahap pengalaman di sampaikan dengan pelan kepada mereka.

Pengalaman para remaja karang taruna akan terlihat pada sisi moral atau akhlaq jika benar-benar menyatu kemampuan pengalaman spiritual mereka dengan menonjolkan rendah hati, tidak takabbur, dan menjunjung tinggi norma agama. Maka buah hasil dari pengalaman spiritual ialah menggerakkan dirinya menjadi insan berbudi.

Memang dalam dunia tasawuf perlu yang namanya pengalaman seperti pengalaman dalam dirinya maupun dalam agamanya. Karena pada hakikatnya manusia tidak dapat keluar dari persoalan tersebut, bahkan manusia modern sekalipun. Dalam kaitan dengan pengalaman manusia semacam itulah, agama berfungsi memberikan transendensi pengalamanpengalaman sehingga dapat dikatakan bahwa pada hakikatnya agama

\footnotetext{
${ }^{15}$ Nilai Keagamaan Yang Dimaksud Ialah Implementasi Keilmuan Kitab Hikam Yang Sudah Di Implikasikan Pada Penerapan Budi Luhur Serta Akhlaq Antara Tuhan Dengan Manusia Juga Ahklaq Manusia Dengan Sesama
} 


\section{8 ][ Penanaman Spiritual Remaja Karang Taruna Melalui Pengkajian Kitab Hikam}

adalah suatu pengalaman manusia berhadapan dengan Allah Swt. Untuk menelaah pengalaman keagamaan tersebut terdapat dua kemungkinan. ${ }^{16}$

Pertama, memandang pengalaman tersebut sebagai sesuatu yang hanya dapat dialami secara kolektif. Kemungkinan kedua, memahami pengalaman sebagaimana dialami oleh orang-orang secara perorangan. Ada dua cara untuk mengetahui mengenai hakikat pengalaman keagamaan. Cara pertama adalah dengan menggunakan deskripsi sejarah agama, sekte atau aliran pemikiran keagamaan itu sendiri. Cara kedua adalah dengan mengajukan pertanyaan di mana aku, yaitu lingkungan potensial di mana pengalaman perseorangan berlangsung.

Pengalaman apapun sangat penting sehingga ketika pengalaman sudah ada tinggal bagaimana cara memperbaiki dari hal-hal yang kurang menjadi kesempurnaan. Sama halnya ketika spiritual diterapkan maka tidak lepas dengan implementasi pengalaman yang harus ia lewati dalam proses spiritual.

2. Pembiasaan

Menanamkan sifat Pembiasaan kepada remaja karang taruna memang bukan mudah, ustadz masruh atau pimpinan dari majelis taklim desa karangrejo menanamkan karakter sifat kebiasaan kepada remaja karang taruna butuh proses panjang hingga bertahun-tahun lamanya. Banyak cara yang beliau lakukan terhadap pemuda karang taruna sebagai konsep pembiasaan seperti mengajarkan kitab al-Hikam, mengingatkan istiqomah membaca wirid tingkat dasar, memfasilitasi rutinitas membaca râtib al-Haddad setiap minggu sampai mereka sudah terbiasa melaksanakannya. ${ }^{17}$

Sifat remaja karang taruna sebelumnya tidak sebagus sekarang. Mereka dulu sangat arogan bahkan cenderung brutal, maka menghapus sikap tersebut dan mengganti menjadi sikap bermoral sangat butuh waktu lama. Ada salah satu ungkapan Ustadz Masruh saat interview sebagai berikut:

"anak-anak pemuda atau lingkungan remaja karang taruna dulu disini sering mendem (mabuk-mabukan), judi dan sebagainya.

\footnotetext{
${ }^{16}$ Ahmad Nurcholis, "Tasawuf Antara Kesalehan Individu Dan Dimensi Sosial." Teosofi: Jurnal Tasawuf Dan Pemikiran Islam 1.2 (2011): 175-195, Hal 181

${ }^{17}$ Peneliti Menggali Data Dari Observasi Dimana Peneliti Menggali Data Dari Keikutsertaan Kegiatan Pada Hari Rabu Dan Kamis Pada Tanggal 20, 21 Februari 2019
} 
sekarang mengikuti amaliah ratibul hadad dan belajar hikam itu bisa berubah derastis dengan kegiatan itu" 18

Pendekatan yang dilakukan ustadz masruh tergolong sukses dalam memengaruhi karakter pemuda remaja karang taruna yang asalnya arogan menjadi pemuda yang baik serta bisa mengimplementasikan nilai-nilai ajaran yang ada dalam kitab al-Hikam.

Pembiasaan yang dilakukan untuk remaja karang taruna memang sangat cocok dalam pendidikan akhlak bagi pemuda karena akan lebih efektif dalam pembentukan akidah dan pelurusan akhlak sebab pendidikan dengan menggunakan pendekatan tersebut selalu mendasarkan pada perhatian dan pengikut sertaan kepada murid yang diajarkan. ${ }^{19}$

Dalam teori lain disebutkan bahwa pembiasaan merupakan Perilaku pada kebiasaan yang tetap melewati dua tahap yaitu proses pemuasan motivasi-motivasi fitrah dan perolehan yang ingin dipuaskan, baik yang materi maupun mental. Dalam melihat karakteristik perlu dilihat dan ditinjau melalui tahap-tahap dalam membentuk suatu kebiasaan diantaranya mujahadah, pengulangan dan pengawasan.

Mujahadah dimaksudkan Kemauan seorang remaja untuk komit dalam ketaatan, karena tidak akan terwujud dengan mudah sekedar niat. Hal itu didahului dengan perjuangan panjang dan berat, dengan mobilisasi motivasi-motivasi iman dalam jiwa, siap menolak dorongan hawa nafsu dan syahwat keduniaan yang selalu berusaha di bangkitkan oleh setan.

Penanaman dengan pembiasaan melalui mujahadah tidak mudah remaja karang taruna di desa karangrejo. Dipupuk dengan siraman rohani setiap minggunya agar mampu memobilisasi motivasi iman dalam jiwa serta diawasi dalam persepektif doa-doa yang diberikan ketika pengkajian hikam agar meminimalisir dorongan nafsu dan syahwat. Hanya remaja yang telah mengenal tabiat mujahadah dan menetapkan niat serta bertawakal kepada Allah yang dapat melakukannya. Dan nantinya Allah akan memenuhi janji-Nya yaitu dengan memberikan hidayah ke jalan yang lurus. $^{20}$

\footnotetext{
${ }^{18}$ Masruh, Pimpinan Majelis Taklim, Wawancara, Karangrejo, 14 Mei 2019.

19 Mukaromah, Ulin Nailatul. Metode Pembiasaan Kegiatan Keagamaan (Studi Pada Kegiatan Intrakurikuler Di Mts Negeri Model Pemalang). Diss. Iain Walisongo, 2012. Hal 7

20 Fitri Nur Fadhila. "Peran Kepala Madrasah Dalam Meningkatkan Kecerdasan Spiritual Siswa Melalui Pembiasaan Praktik Keagamaan Di Mi Al-Falah Kanigoro Blitar." (Skripsi, Uin-Malang: 2014). Hal 42
} 


\section{0 ][ Penanaman Spiritual Remaja Karang Taruna Melalui Pengkajian Kitab Hikam}

Teori pembiasaan selanjutnya dengan cara Pengulangan perilaku secara terus-menerus merupakan tahap asasi dalam membentuk kebiasaan secara umum. Karena, pengulangan perilaku dengan cara tertentu membuat perilaku tersebut tertanam dalam jiwa, sehingga jiwa tidak menemukan lagi kesulitan yang dirasakannya pada saat memulai menjalani awal-awal tahapan pembentukan kebiasaan. Dalam hal ini selang beberapa waktu jiwa sudah cenderung melakukan perilaku tersebut dengan mudah. Sehingga orang yang melihat akan merasa seolah-olah perilaku tersebut dilakukan tanpa kesadaran pikiran dan kehendak. ${ }^{21}$

3. Emosional

Emosional yang dibangun dalam perkembangan remaja karang taruna desa karangrejo meliputi banyak hal. Kegiatan-kegiatan rutinitas semisal pada hari rabu yaitu melakukan wirid ratib al-haddad dan di tutup dengan kajian kitab al-Hikam, kegiatan tersebut bisa mendorong emosi para remaja karang taruna menjadi lunak dan tidak cenderung ekstrem.

Salah satu ungkapan peserta jamaah dari luar desa karangrejo yang bernama mas tatok pernah menyampaikan kepada peneliti, sebagai berikut;

"saya bekerja di perusahaan dan gaji yang saya peroleh hanya saya buat senang-senang semisalnya mabuk-mabukan, madon (berzina), judi dan sebagainya, pokok hampir tiap hari tidak lepas dari minuman keras apalagi kalau ada teman perusahaan yang ulang tahun pasti minuman keras menjadi kosumsi wajib bagi saya dan teman-teman. Dan sifat saya sangat keras opomane lek ono seng garai ( apalagi kalau ada yang mau berbuat anarkis kepada saya) tetapi keadaan saya berubah semenjak teman saya mau mengajak ke pengkajian hikam dan ratibul hadad, diri saya yang saya rasakan jauh berbeda dengan dulu"22

Kegiatan kajian kitab al-Hikam sudah banyak hasilnya banyak pernyataan para jamaah yang mengatakan dirinya dulu merupakan remaja yang selalu berbuat negatif dan kemudian bisa berubah secara derastis. Ini menunjukan bahwa sifat emosional dan perasaan yang mereka alami secara bertahap semakin berubah.

Penanaman spiritual melalui pendekatan emosional ini terbentuk dari aspek bahwa keadaan remaja karang taruna yang dulunya mempunyai

\footnotetext{
${ }^{21}$ Ibid, Fitri Nur Fadhila, Hal 43

${ }^{22}$ Indrik Tatok, Jamaah Ratibul Hadad, Wawancara, Karangrejo, 7 Maret 2019
} 
kekurangan-kekurangan dalam hal pergaulan yang baik, spirit sosial yang kurang baik maka dengan pengkajian kitab hikam bisa melunakkan hati mereka sehingga yang dulu-dulu mereka alami bisa dijadikan alat ukur supaya kedepannya bisa ia jauhi dan tidak terpengaruh dengan lingkungan yang tidak baik.

Dalam penguat lainnya peneliti juga menyebutkan dalam teori Endah Purwanti ialah Penggunaan pendekatan emosional dalam penanaman nilai-nilai akhlak dianggap paling sesuai. Karena mereka sedang pada masa tahap perkembanngan The Realistic Stage (tingkat kenyataan). Pendekatan emosional menekankan pada hubungan baik, menyelami perasaan remaja dan kasih sayang. Keunggulan pendekatan emosional yakni; guru dapat memahami perasaan murid, serta murid merasa senang dengan guru tersebut dan mau mengikuti pelajaran dengan baik. Cara guru dalam menggunakan pendekatan emosional sebelum menyampaikan kajiannya yaitu dengan menganalisis keadaan murid atau peserta didik. ${ }^{23}$

Jadi kesimpulannya ialah perubahan-perubahan emosional dan sikap para remaja karang taruna bisa terjadi dengan sendirinya melalui tahap demi tahap dalam menanamkan spiritual tentunya didorong dengan kegiatan bersifat agama salah satunya dengan adanya kajian kitab alhikam di Desa karangrejo.

4. Rasional

Pengkajian kitab hikam yang dilakukan di desa karangrejo tidak hanya mengajarkan bagaimana menjelaskan lingkup tasawuf seperti; hidup harus zuhud, harus istiqomah beribadah dan sebagainya. Yang diajarkan dalam kajiannya juga menyindir tentang ajaran keseharian dalam hal bermuamalah baik dan benar bersosial dengan sesama teman dengan santun.

Rasional dalam konteks ini ialah pengajaran syariat dalam implementasi sehari-hari. Terutama hal ibadah sosial seperti yang berhubungan dengan masyarakat bagaimana supaya lebih bijak dan mampu mengimplementasikan ajaran-ajaran tasawuf dengan realitas sosial kemasyarakatan. Rasionalitas bagi tahapan remaja ialah mampu menerima ajaran tasawuf dengan pola fikir yang rasional dan mengimplementasikan

23 Endah Purwanti, Penggunaan Pendekatan Emosional Dalam Penanaman Nilai-Nilai Akhlak Di Sd Muhammadiyah Karang Bendo Banguntapan Bantul Yogyakarta, (Skripsi, Uin-Suka, Yogyakarta: 2013), Hal 4 


\section{2 ][ Penanaman Spiritual Remaja Karang Taruna Melalui Pengkajian Kitab Hikam}

ajaran dengan pola pikir yang fleksibel sehingga tidak mudah dalam menjustifikasi dirinya lebih baik dari pada orang lain. Maka sangat penting ajaran ini bisa merasuk pada jiwa pemuda remaja karang taruna karena hal mendasar ini mampu menjadi pemuda yang bisa dijadikan patokan moral bagi lingkungan sekitar.

Dalam ajaran hikam sendiri pernah menyinggung perintah yang rasional untuk bisa di implementasikan dalam kehidupan sosial, seperti pernyataan idfin wujudzaka fî al-ardzi al-khumul" "tanamlah wujudmu di dalam tanah yang hina" maksud penggalan kalimat dari kitab hikam tersebut Ketika seorang pemuda yang tidak mempunyai etika dalam bersosial atau tidak rendah hati dengan masyarakat maka yang akan terjadi hanyalah masyarakat menilai buruk, tetapi sebaliknya jika remaja yang punya nilai tawadhu' atau rendah hati di tengah-tengah masyarakat maka masyarakat menilai dengan perolehan nilai yang positif dan jika terlihat positif baik maka keberadaanya akan diterima di masyarakat dan ajaran yang rasional merupakan ajaran yang mampu diterima di masyarakat dan disegani oleh kawan lainnya.

Ajaran tasawuf kitab al-Hikam harus diterima melalui rasional sehingga pemuda karang taruna cenderung belajar berfikir mengenai halhal positif tentang ajaran tasawuf dan paling penting setelah belajar ialah dengan cara mengamalkannya.

5. Fungsional

Kajian kitab al-Hikam merupakan salah salah satu kegiatankegiatan yang diterapkan oleh karang taruna desa karangrejo merupakan banyak kemanfaatan yang bisa diperoleh dan amalkan dalam kesehariannya.

Seperti yang diungkapkan saudara fauzi anggota karang taruna yang hadir dalam kajian kitab hikam sebagai berikut: ${ }^{25}$

"Lebih tenang hati, terus ilmu tentang agama didapat dapat nambah wawasan, bisa bersosialisasi dengan orang yang sebelumnya tidak dikenal, ilmu agama yang sebelumnya belum diketahui dari sekolah-sekolah atau ngaji-ngaji yang lain sekarang lebih paham"

\footnotetext{
${ }^{24}$ Pernyataan ini peneliti peroleh dari ucapannya ustadz masruh selaku pimpinan dan pengasuh majelis taklim ketika peneliti bertanya tentang hakikatnya idfin wujudzaka fi alardzi al-khumul yang diimplikasikan kepada pemuda karangtaruna, tanggal 22 juni 2019

${ }^{25}$ Fauzi Kojek, Remaja Karang Taruna, Wawancara, Karangrejo, 14 Mei 2019.
} 
Ungkapan tersebut merupakan bukti real keadaan mereka setelah mengikuti kegiatan kajian kitab hikam yang tentu ada hasilnya. Ia bisa merasakan sendiri apa yang selama ia ikuti. Penanaman spiritual yang diajarkan di desa karangrejo merupakan bagian dari kegiatan-kegiatan islam berkarakter. Berakar dari kitab hikam yang mengajarkan dunia tasawuf tetapi uniknya tasawuf seakan-akan ditarik garis bawahi bahwa dapat disimpulkan dengan realitas sehari-hari.

Jadi fungsional dari kegiatan kajian kitab hikam ialah mereka mampu menyadari sendiri sebab akibat dari pelaksanaan yang istiqomah banyak berakibat baik terhadap dirinya sendiri sehingga kemanfaatan meliputi secara dhohir dan batin.

6. Keteladanan

Sebagai Pimpinan jam'iyah majelis taklim sekaligus pengasuh terhadap remaja karang taruna desa karangrejo, ustadz masruh memberikan contoh perilaku yang baik dengan berbagai perilaku keseharian dan menonjolkan sifat kesederhanaan sebagai wujud arti dari keteladanan itu sendiri. Beliau ketika menyuguhkan ilmu hikam kepada para hadirin yang hadir selalu mengawali dengan istilah tawasul. Karena dengan tawasul sendiri merupakan cerminan keteladan sebagai bentuk syukur kepada ilmu yang beliau peroleh dari gurunya.

Tawasul kepada alim 'ulama serta sanad keilmuan merupakan keteladan yang baik yang perlu dicontoh oleh siapapun. Karena secara otomatis kita tidak melupakan pendahulunya. Bentuk kesalehan lainya seperti bentuk keteladanan ${ }^{26}$ yang mampu diimplikasikan dari gaya kepemimpinan karang taruna yang saat ini mulai banyak berkembangnya kegiatan keagamaan di dalam desa karangrejo seperti maulid addzibaiyah, partisipasi dzikr al-ghofilin, ikut serta kajian kitab al-Hikam satu minggu sekali dan sebagainya.

Keteladanan yang diberikan kepada remaja karang taruna sangat simple dan selalui dikit demi sedikit. Dalam perkembangan pendekatan keteladanan yang di bina di karangrejo ini ada beberapa tahapan diantaranya; melalui ceramah kisah-kisah ulama teladan yang diambil dari kitab hikam sendiri, adapula sifat keteladanan dibangun melalui

\footnotetext{
${ }^{26}$ Diperoleh dari keikutsertaan peneliti dalam kegiatan karang taruna di desa karangrejo kecamatan gempol pada 19 juni 2019
} 
pengenalan ulama-ulama sekitar pasuruan dengan cara berziarah dan mendalaminya.

Seringkali ustadz masruh selaku pimpinan dan pengasuh majelis taklim di desa karangrejo menceritakan kisah seorang ulama' dan wali Allah dari bangil yaitu sayyid abdullah sangeng. Beliau menceritakan bagaimana kisah beliau ketika bersosial beribadah serta ketika mendidik muridnya, inilah salah satu yang mungkin dipertontonkan sebagai keteladanan yang mesti dikerjakan oleh remaja karangtaruna.

Kisah-kisah ulama lain yang banyak yang sudah diceritakan dan publikasikan berharap menjadi contoh perilaku bagi pemuda saat ini. Kadang beliau juga menceritakan kedaan guru spiritualnya sendiri yang bernama haji muhammad shohib yang selama hidupnya banyak mengabdi dan membimbing umat sehingga sukses dalam mendirikan jam'iyah sholawat di daerah bangil.

Jadi sifat keteladanan yang sudah diberikan memang harus dilaksanakan sesuai porsi masing-masing atau sesuai kemampuannya. Sebagai contoh pada bagian keteladanan merupakan hal positif yang harus ditanam dan diamalkan dalam oleh prilaku spiritual terlebih lagi kepada remaja karang taruna desa karangrejo.

\section{PENANAMAN SPIRITUAL REMAJA KARANG TARUNA DI DESA KRANGREJO KECAMATAN GEMPOL}

Rutinitas kegiatan penanaman spiritual di desa karangrejo banyak cara yang dilakukan. Dalam setiap minggunya ada beberapa kegiatan yang bisa diikuti oleh kalangan pemuda karangtaruna. Kegiatan keagamaan yang ada di desa karangrejo didukung penuh oleh kalangan masyarakat pribumi karena kegiatan keagamaan sangat cocok buat mengisi kekosongan diselasela kesibukan bekerja.

Adapun kegiatan penanaman spiritual yang ada di desa karangrejo meliputi; kajian kitab hikam, pembacaan wirid ratib al-Haddad, wirid tingkat dasar serta setiap bulan di tempat tersebut mengadakan ziarah kemakam sesepuh dan ulama sekitar pasuruan.

1. Melalui Kajian Kitab Hikam

Kegiatan kajian kitab al-hikam dilaksanakan pada hari rabu setelah shalat isya'. Penetapan kegiatan hari rabu ini ditetapkan sebagaimana dulu para penduhulu banyak yang mengamalkan pada hari rabu tepatnya malam 
kamis. Ada juga yang berpendapat bahwa hari rabu malam kamis merupakan hari yang baik untuk mengamalkan amaliah Ratib al-Haddad.

Pada kegiatan ini peserta remaja karang taruna diharuskan datang setelah shalat waktu isya' serta on time karena mengingat supaya tidak terlalu malam dalam melaksanakan kegiatan pembelajaran hikam tersebut. Yang hadir dalam kegiatan tersebut sebetulnya tidak hanya dari kalangan remaja setempat tetapi banyak pula yang dari luar karena itu jamaahnya semakin tahun semakin bertambah.

Ada beberapa cara ketika pembelajaran hikam yang ada di desa karangrejo diterapkan diantaranya dengan ceramah, cerita kisah-kisah dan juga implementasi. Adapun penjelasannya sebagai berikut;

Pertama, pengkajian kitab hikam ketika disampaikan oleh sang guru/ustadz tidak lepas dari penyampaian materi secara langsung, secara detail dan bisa memahamkan peserta yang hadir. Ceramah bukan hanya menyampaikan materi belaka tetapi bagaimana seorang guru mampu menyakinkan apa yang selama ini diperoleh dan diaplikasikan ke dalam lingkungan. Karena ceramah juga untuk mentransfer pengetahuan dari yang tidak tahu menjadi paham.

Kitab al-Hikam yang dipakai mengajar oleh sang ustadz ialah kitab kuning, maka untuk memudahkan para remaja karang taruna yang hadir, maka dilakukan dengan ceramah, terkait yang disampaikan ialah apa yang ada di dalam kitab tersebut. Setiap pertemuan yang disampaiakn hanya hikmah justru yang paling banyak disampaiakan ialah cerita-cerita.

Kedua, pengkajian kitab hikam juga dilakukan dengan cara bercerita atau mengulang sejarah masa lampau tentang kehidupan seorang sufi. Cerita dalam pengakajian hikam dilakukan sesuai tahapan atau sesuai bab yang dikaji. Jadi menceritakan seorang tokoh sufi yang dimana ia punya penonjolan karakter yang ia peroleh selama hidup. Misalnya rabiatul adawiyah dengan peran mahabbahnya, abi yazid al-Bustami perannya dengan sifat kezuhudannya, imam al-Ghazali perannya dengan ketasawufannya.

Semua tentang cerita-cerita sengaja disampaikan agar bisa memberi motivasi spiritual serta memberi rangsangan agar para pemuda karang taruna mau bersinergi dengan apa yang disampaikan. Manfaat bercerita bisa membangkitkan semangat dan banyak hal-hal positif yang bisa diambil. 
Ketiga, tentang implementasi merupakan hal-hal yang terakhir yang mesti dilakukan oleh remaja karang taruna agar selama yang mereka jalani bisa terealisasi. Implementasi juga sangat penting buat pengukuran keberhasilan selama yang diajarkan oleh ustadz dengan cara berceramah ataupun dengan memberikan qisshoh (cerita) letak pencapaianya yang terakhir dengan implementasi.

2. Pembacaan Râtib al-Haddad

Pembacaan râtib al-Haddad merupakan agenda kegiatan rutinitas remaja karang taruna desa karangrejo. Pembacaan râtib al-Haddad merupakan salah satu bentuk penanaman spiritual yang digagas sejak lama sekitar tahun 2005. Dulunya yang mengikuti hanya kalangan pribumi karangrejo semata tetapi sejak tahun 2013 perubahan derastis pesertanya dari lingkungan manapun boleh ikut, Jadi peserta râtib al-Haddad di desa karangrejo semakin bayak.

Khasiat râtib al-Haddad tidak diragukan lagi selain para pemuda diajarkan kitab hikam mereka harus didorong dengan wirid tersebut agar keistiqomahan para pemuda karangtaruna terus melekat sehingga memunculkan keteguhan dalam hatinya untuk mengamalkan ajaran spiritual dengan baik.

Beberapa ungkapan khasiat râtib al-Haddad yang disampaikan oleh ustadz masruh ialah; Pada saat setelah lumpur lapindo keluar dari bumi, langit di Gempol terasa kelihatan api sehingga terlihat suasana yang panas, beliau punya inisiatif ingin mercikan segelas air untuk dipercikan ke atas langit, pada saat beberapa jam langit tersebut mulai mendung dan akhirnya hujan lebat di daerah Gempol. Masyarakat Gempol pada saat itu senang dengan kedatangan hujan yang sebelumnya tidak kunjung datang, mereka menyakini bahwa hujan tersebut merupakan hal baik yang akan datang. Seketika itu pada saat masih derasnya hujan ustadz masruh mewadahi air hujannya beberapa gelas, dan kemudian dibawa air tersebut ke mbah Salim yang ada di Desa Kemuning. Pada saat itu mbah Salim meminum air dari yang bekas air hujan tersebut. Setelah meminum mbah Salim menyatakan bahwa isyarah itu benar adanya dan ustdaz Masruh merasa lega dan ingin terus memupuk amaliah ini sampai akhir.

Penanaman spiritual dalam mewujudkan peranannya kepada tujuan atau hasil yang nyata harus ada dorongan batin yang sangat kuat. Dorongan itulah dinamakan Doa, karena doalah yang bisa merubah sikap sosial dan spiritual agar dekat dengan Allah Swt. Doa dalam konteks ini 
ialah pembacaan râtib al-Haddad, pengamalan râtib al-Haddad Pada dasarnya kegiatan yang selalu di jaga oleh remaja karang taruna agar setiap langkahnya mampu memproyeksikan nilai-nilai keagamaan sebagaimana yang telah diajarkan dalam forum pendidikan keagamaan di desa karangrejo.

3. Mengamalkan Wirid Tingkat Dasar

Pengamalan wirid tingkat dasar merupakan lanjutan dari kegiatan râtib al-Haddad oleh karang taruna di desa karangrejo. Pemuda karang taruna yang sudah mengikuti kegiatan hari rabu yaitu râtib al-Haddad dan kajian kitab hikam mereka juga dianjurkan mengikuti kegiatan ini supaya bisa sempurna pengamalannya.

Kegiatan ini dilaksanakan setiap hari kamis malam jum'at yang jumlahnya agak banyak dibandingkan hari rabu. Pengamalan wirid tingkat dasar ini dulunya ijazah langsung dari gurunya ustadz masruh yaitu haji muhammad shohib dari bangil kabupaten pasuruan. Pengamalan wirid tingkad dasar di dalamnya mengandung sekumpulan wirid yang sudah mashur di terapkan oleh wirid-wirid yang lain cuma bedanya pengamalannya dilalui dengan syarat tertentu diantaranya; berpuasa dua hari, setiap kali puasa pada malam harinya harus mengamalkan wirid tersebut dan ketika sudah mulai puncak malam terakhir ditambah dengan mengamalkan surat yâsîn 3 kali.

Alasan mengamalkan wirid ini dianjurkan karena beberapa alasan yang diungkapkan oleh ustadz masruh yaitu; wiridan tingkat dasar itu bisa dibuat wadah dalam kesehariannya, seperti halnya ketika seseorang mempunyai komitmen dalam mengamalkan wirid harus ditampung dengan wadah yang mewadahi wirid tersebut, supaya wirid tersebut bisa terjamin dan tidak bisa tumpah dengan sendirinya. Tetapi seseorang tidak punya wadah dalam mengamalkan amaliah bisa dipastikan tumpah dan sia-sia yang ia lakukan.

\section{DAFTAR PUSTAKA}

Adibah, Ida Zahara. 2017 "Pendekatan Sosiologis Dalam Studi Islam." INSPIRASI: Jurnal Kajian dan Penelitian Pendidikan Islam vol. 01 no. 01

Ainiyah, N, 2013. Pembentukan Karakter Melalui Pendidikan Agama Islam. Al-Ulum, vol. 13 no. 1 
338 ][ Penanaman Spiritual Remaja Karang Taruna Melalui Pengkajian Kitab Hikam

Anwar, Chairul, 2014 "Internalisasi Semangat Nasionalisme Melalui Pendekatan Habituasi (Perspektif Filsafat Pendidikan)." Analisis: Jurnal Studi Keislaman vol.14 no.1

Arifuddin, Muhammad, 2018, Corak Tasawuf Kitab Hikam Karya Ibn 'Athaillah As-Sakandari Dan Implikasinya Dalam Pembentukan Akhlak Di Pondok Pesantren Mambaus Sholihin Suci Manyar Gresik, Masters Thesis, UIN Sunan Ampel Surabaya.

Aziz, Rahmat. 2019 "Pengalaman Spiritual Dan Kebahagiaan Pada Guru Agama Sekolah Dasar." Jurnal Proyeksi vol 06 no. 2

B. B. B. Achmad 2016, Pemikiran Ibnu Athaillah As-Syakandari Tentang Pendidikan Sufistik Dan Relevansinya Dengan Pendidikan Karakter Di Indonesia (Telaah Kitab Al-Hikam Al-Atiyah), Tesis, Jurnal Uin Maliki.

Cahyono, Heri. 2016 "Pendidikan Karakter: Strategi Pendidikan Nilai Dalam

Membentuk Karakter Religius." Ri'ayah: Journal Of Social And Religious vol.01 no.02

Cahyono, Rudi. 2012 "Dinamika Emosi Dan Pengalaman Spiritual

Beragama: Studi Kualitatif Pengalaman Perubahan Keyakinan Beragama." Jurnal Insan Media Psikologi vol 13 no.1

Departemen Agama RI, 2012, Al-Qur'an Dan Terjemahannya, Surabaya: Fajarmulya.

Dewi, N. L. L. A. Dll 2014. Analisis Nilai-Nilai Pendidikan Karakter Novel Sepatu Dahlan Karya Khrisna Pabichara dan Relevansinya terhadap Pengajaran Pendidikan Karakter Sekolah di Indonesia. Jurnal Pendidikan Bahasa dan Sastra Indonesia Undiksha, vol.2 no.1

Endrayani, Endah, 2012. Pembinaan Moral Spiritual Siswa Melalui Pembiasaan Shalat Jamaah (Studi Analisis Siswa MTs Miftahussa'adah Mijen Semarang) (Doctoral dissertation, IAIN Walisongo).

Gafara, C., Riyono, B., \& Setiyawati, D. (2017). Peran Karang Taruna Dalam Pemberdayaan Penyandang Disabilitas Di Desa Karangpatihan, Kabupaten Ponorogo Dan Implikasinya Terhadap Ketahanan Ekonomi Keluarga. Jurnal Ketahanan Nasional, nomer 23 volume 01 Jauhari, M. A. 2017. Perilaku Sosial Santri Pondok Pesantren Al-Ishlah Bandar Kidul Mojoroto Kota Kediri Setelah Mengikuti Pengajian Kitab Al-Hikam. jurnal Spiritual, vol. 1 no.1 
Johan Eka Saputra, 2017, Strategi Penanaman Nilai-Nilai Spiritual Dalam Meningkatkan Prestasi Belajar Pendidikan Agama Islam Siswa (Thesis, Studi Multisitus Pada Smpn 1 Bandung Dan Smpn 2 Bandung Tulungagung.

Khotimah, Muna Husnul, 2018, Penanaman Sikap Spiritual Dan Sikap Sosial Melalui Pembelajaran Mapel Pai Di Smk Islam Surakarta Tahun Ajaran 2018/2019 Skripsi, Iain Surakarta.

Maya, Rahendra. 2017 "Revitalisasi Keteladanan Dalam Pendidikan Islam: Upaya Menjawab Peluang Dan Tantangan Pendidikan Islam Di Era Masyarakat Ekonomi Asean (Mea)." Edukasi Islami: Jurnal Pendidikan Islam Vol.09 No.12

Miftahul Jannah, 2017, Remaja dan Tugas-tugas Perkembangannya dalam Islam. Psikoislamedia: Jurnal Psikologi, Vol.1 No.1

Muhammad Sholikhin, (2008) Filsafat Dan Metafisika Dalam Islam (Sebuah

Penjelajahan Nalar, Pengalaman Mistik, Dan Perjalanan Aliran Manunggaling Kawula Gusti), Narasi, Yogyakarta.

Muhtadi, Ali, 2007, "Teknik Dan Pendekatan Penanaman Nilai Dalam Proses Pembelajaran Di Sekolah." Majalah Ilmiah Pembelajaran vol. 3 no.1

Nuwairotul Layaliya, 2016, Penanaman Nilai-Nilai Pendidikan Agama Islam

Dalam Spiritual Company Dan Implikasinya Terhadap Perilaku Keagamaan Karyawan Waroeng Steak And Shake Yogyakarta (Skripsi, Uin-Suka Yogyakarta

Purwanti, Endah, 2013, Penggunaan Pendekatan Emosional Dalam Penanaman Nilai-Nilai Akhlak Di Sd Muhammadiyah Karang Bendo Banguntapan Bantul Yogyakarta, Skripsi, Uin-Suka, Yogyakarta.

Rahem, Zaitur, (2017), Ajaran Pendidikan Anti Korupsi Ibnu Athaillah(Menggali Nilai Pendidikan Moral-Spiritual Dsari Sebagian Untaian Hikmah Kitab Al-Hikam), Jurnal Pendidikan Dan Manajemen Islam, Volume 6, Nomor 2

Rahman, Ali, (2016), Pengaruh Negatif Era Teknologi Informasi Dan Komunikasi Pada Remaja (Persepektif Pendidikan Islam), Jurnal Studi Pendidikan, Vol 14 No. 1

Rohman, Abdul, 2016 "Pembiasaan Sebagai Basis Penanaman Nilai-Nilai Akhlak Remaja." Jurnal Nadwa nomer 6 volume 01.

Rokhmah, Hidayatu. 2016, Penanaman Nilai-Nilai Spiritual Terhadap Peserta Didik Di Ds It Harapan Bunda Purwokerto, Skripsi, Iain Purwokerto. 
340 ][ Penanaman Spiritual Remaja Karang Taruna Melalui Pengkajian Kitab Hikam

Sholeh, Mohammad, 2019, Peran Masjid Abdurrohim Dalam Meningkatkan Spiritual Personel Tni Au Di Komplek Lanud Adisutjipto Yogyakarta, Skripsi, Uin-Suka Yogyakarta.

Solikin, Ahmad, (2015). Bimbingan Spiritual Berbasis Nilai-Nilai Budaya. Al-Tahrir: Jurnal Pemikiran Islam, vol.15 no.1

Suhono, Suhono, And Ferdian Utama. 2017, "Keteladanan Orang Tua Dan Guru Dalam Pertumbuhan Dan Perkembangan Anak Usia Dini." Elementary: Jurnal Ilmiah Pendidikan Dasar vol. 3 no. 2

Suramto, (2009) Pembinaan Akhlak Pelajar Berprestasi Melalui Bimbingan Mental Spiritual (Bms) Di Yasr Klaten (Skripsi, Uin Sunan Kalijaga Yogyakarta)

Uli Fajriyah, 2015, Implementasi Pndekatan Emosional Dalam Pembelajaran Aqidah Akhlak Di Mi Muhammadiyah 2 Karangtengah Kecamatan Kemengkon Kabupaten Purbalingga, Skripsi, Iain Purwokerto.

Yasmin, Amalia Oktavia, 2017, Efektifitas Pendekatan Spiritual Dalam Meningkatkan Percaya Diri Siswa Tunarungu, Progam Pasca Sarjana, Uin-Maliki Malang. 